\title{
Inviting construction: Primark, Rana Plaza and Political LEGO.
}

Ian Cook et al, University of Exeter

Forthcoming in Transactions of the Institute of British Geographers

\section{Introduction: when you argue with your toys}

Weird. Shocking. Tasteless. Ridiculous. Funny. Uncomfortable. Wrong. Memorable. In January 2012, South Park figurines, teddy bears, over 200 toys stood in a Siberian city's snow holding protest signs 'complaining about corruption and electoral malpractice' (O'Flynn 2012 np). In September 2015, a London Freedom of Expression exhibition showed Sylvanian Families scenes in which 'MICE-IS, a fundamentalist Islamic terror group, are threatening to dominate Sylvania, and annihilate every species that does not submit to their hardline version of sharia law' (Armistead \& Jones $2015 \mathrm{np}$ ). A month later, a comedy writer posted online scenes from the Greek financial and refugee crises recreated in Playmobil, including one in which 'a crammed boat sails the ocean while a mother cradles a young boy - which calls to mind the three-year-old Syrian refugee Alyan Kurdi whose body was washed up on the Turkish seaside' (Sayev $2015 \mathrm{np}$ ). Each was banned, censored and discussed in multiple press stories around the world.

For some, such examples of commodity art-activism might illustrate precisely the kind of 'postmodern playfulness' from which critical geographic theory needs to be liberated in order to 'return to questions of justice, poverty, exploitation, environment and ... the commodity' (Hartwick in Cook and Woodyer 2012 238). This paper argues the opposite: that such theory "can usefully employ a critical sense of playfulness to engage with these questions through consumer culture' and its commodities (Cook and Woodyer 2012 238). It develops the argument that 'hacking, tinkering and playful exploration' with materials can be generative of novel ideas and theorizations (Gross and Do 2009 213, Carr and Gibson 
2016, Ratto et al 2014) and can lead to forms of 'tender, fleshy, geographic expression that can 'breathe life' into the humanity of a geographical event or situation, allowing for a 'visceral resonance" (Sherry and Schouten in Madge 2014 181). And it experiments with forms of academic expression that can allow such work to come alive on the pages of an academic journal like this (see Lehmann 2012, Madge 2014, Marston \& De Leeuw 2013).

This paper showcases our experiments in commodity art-activism which have included recreating in LEGO scenes from the tense and changing socio-economic relations between investigative journalists, corporate executives and garment workers making clothes for the high street fashion retailer Primark before, during and after the catastrophic Rana Plaza garment complex collapse in April 2013. It is made out of two alternating narratives. One paraphrases journalists' exposés of child labour and catastrophic health and safety failures in garment supply chains and the impacts these are said to have had. The other describes how and what we learned about 're-creating' scenes from these shocking public dramas in LEGO. These narratives are tied together with images of these scenes that we posted online to create a visceral resonance, stir emotion, build theory, question practice, trouble, clarify and invite construction, of our scenes' making, their subject matter and wider questions of justice, poverty and so on. We invite you to look, read and construct argments. With what we show and say. 


\section{Primark: When you decide to attack your critics}

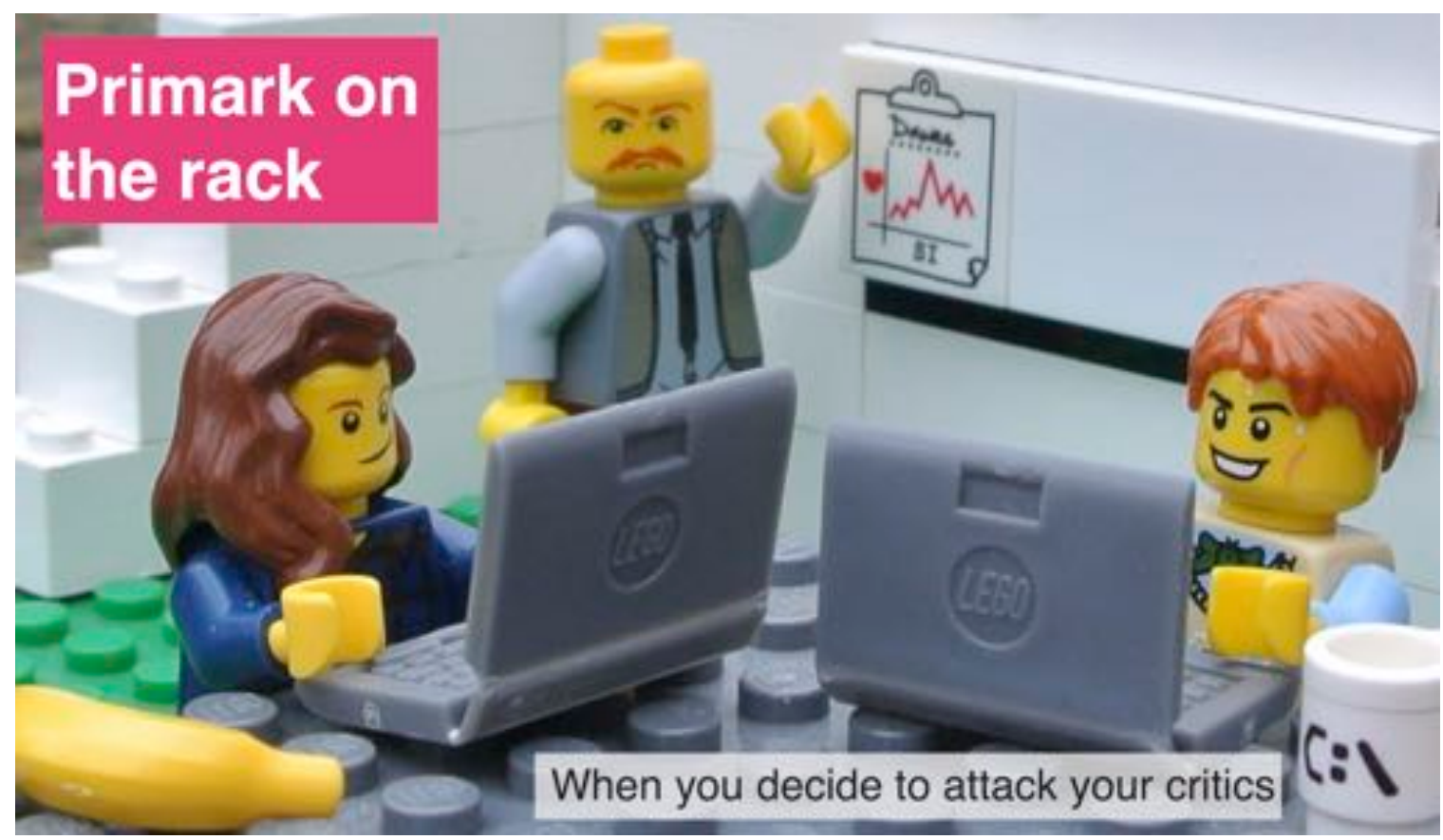

Figure 1.

Our starting point is Primark On The Rack, a TV documentary first broadcast in the UK as part of the BBC's flagship current affairs 'Panorama' series on 23 June 2008 (Adley et al 2013). Three years before, the High Street 'fast fashion' chain Primark was voted the UK's most unethical retailer (Jones et al 2009). Primark On The Rack did little to dispel this. 'Footage was shown of some of India's poorest people working long hours on Primark clothes in slum workshops and refugee camps, far away from the Primark-approved and inspected factories, breaking promises on child labour, working hours and wages' (Sandison 2008 np). On the UK High Street, it showed a 'number of shocked Primark customers watch[ing] in astonishment the videotapes showing child labour working on the very clothes they kept in their wardrobe drawers' (Mezzadri $2011 \mathrm{np}$ ). This was a classic exposé: a reporter travels to the places where everyday branded commodities are made, meets the people making them in illegal, unsafe and/or poorly remunerated circumstances, tries to get the brand to justify this in relation to its published corporate values, and reveals these findings to an unsuspecting consumer audience. 
What was unprecedented about this exposé was the extraordinary public battle that Primark waged with the BBC to undermine its film-making 'truth'. 47 days before the film's broadcast, the BBC involved Primark in a 'right to reply' process, which could have resulted in a Primark spokesperson appearing in the film to answer criticisms. After 'a period of internal debate', however, Primark refused this offer and asked financial and corporate communications consultancy Citigate Dewe Rogerson to handle its media relations for this case (Magee $2008 \mathrm{np}$ ). Primark's response to the documentary, before its broadcast, was to "cancel... new orders with the factories concerned and withdr[a]w thousands of garments from its stores' (McDougall 2008a 22) and to build a micro-website to question the documentary's methods and findings (Jones et al 2009 933). This response, the company believed, would help it to control press responses to the film, by 'mov[ing] the story on' (Lancaster in McDougall 2008a 22) via 'headlines focusing on Primark axing the factories rather than child labour accusations' (Magee $2008 \mathrm{np}$ ). This way, its reputation would be 'repaired before many of its customers will have even noticed it was tarnished' (McDougall 2008a 22). This is not, however, what happened. Primark's strategy was a spectacular failure. Many years later, it would take an unprecedented opportunity to repair its unethical reputation. But only after it had tarnished it even more.

\section{LEGO: When you experiment with digital scholar activism}

There's a page dedicated to Primark On The Rack on followthethings.com (Adley et al 2013). This website is an experiment in digital scholar activism that 'provides information in a strategically structured manner to expresses protest through expertise' (Kneip 2009 192). Starting as an online list in 2008 , it opened as a shopping website in 2011. It names, assembles and researches the 'follow the thing' genre of cultural and scholar activism whose aim is to reveal, appreciate and raise critical questions about relations between the lives of people who make and use everyday things. It assumes its visitors will recognise its 
online store format, and navigate it accordingly. Over eighty examples can be found in its nine departments whose pages contain thumbnail images of each thing followed and a short description of the film, art work, etc. that follows it. Clicking its image or link takes you to an example's full page. Some feature original examples in full, including newspaper articles and student work from the undergraduate module associated with the website. Most pages feature examples like Primark On The Rack that have provoked considerable online debate. Here, textual extracts from a variety of online sources are cut, pasted and arranged in sequence under standard headings describing a) what the example is, b) why, how and by whom it was made, c) how audiences have responded to it, and d) what impacts it is said to have had. Section by section, these read like a long, lively and unfinished conversation about the example (see Cook et al 2014, 2017).

Reading a page like this, you move between different commentators' heartfelt soulsearching, angry outbursts, sarcastic asides, cynical smackdowns, forensic argumentation, ambivalent meanderings, unpredictable twists and turns, from left, right and centre. There is no single expert view. This juxtapositional aesthetic is intended to 'scratch on the imagination' (Beuys in Sacks 2004 x) to leave 'shoppers' thinking about the issues raised long after visiting the website, following links to original sources, sharing what they have found, catalysing conversations with others, elsewhere. To provide a vivid snapshot of each example, a photograph, video trailer and/or other illustration (where there is a Creative Commons license or permission has been granted) starts its page. Where nothing is available, Flickr-hosted images of scenes from each page's unfolding drama are 're-created' in LEGO and embedded in their place. Figure 1 is the first scene made for followthethings.com's Primark On The Rack page: the moment when the company's management team decide to attack the BBC. These LEGO re-creations, we quickly discovered, were popular with our shoppers. 'Not only do [they] produce openly 
assembled bespoke imagery, imagined encounters, and clever juxtapositions,' one told us, 'they invite construction in the literal and figurative sense' (Hockenberry $2013 \mathrm{np}$ ).

Primark: When you allege child labour footage was faked

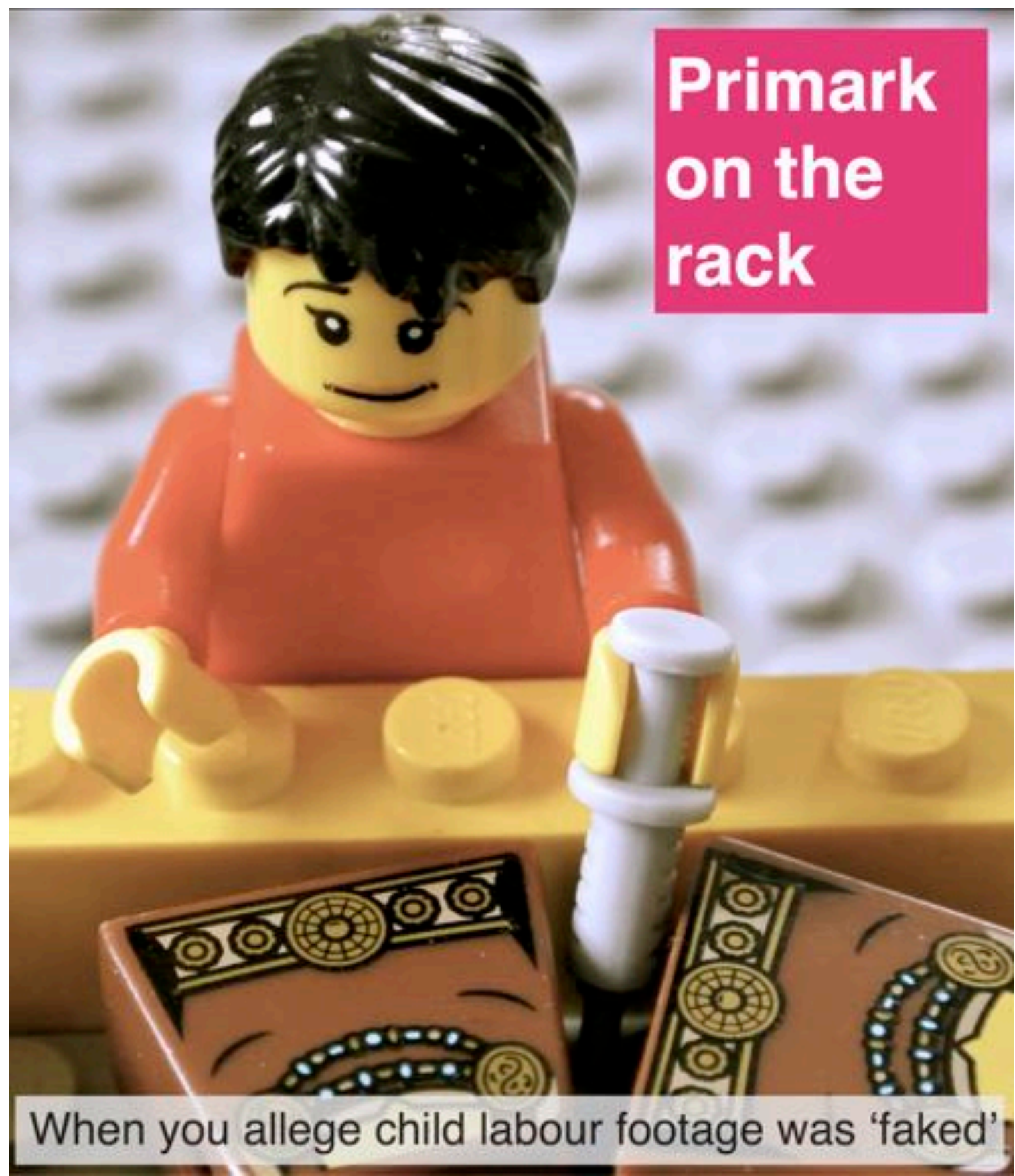

Figure 2.

Primark On The Rack involved seven months of research by a team from BBC Television and the Observer newspaper. Its Associate producer Dan McDougall described the dangers of investigative journalism into India's fashion sweatshops. Packed Buildings. 
Heavily secured basements. Runners and watchmen. Drinking dens. Brothels.

Sweatshops. Being beaten when you're found in one. Being chased through ancient alleyways by angry mobs. Having your equipment smashed. Your translator threatened with death. Local activists intimidated and murdered. That's why big names in fashion escape international exposure. That's why you have to resort to undercover tactics. Pose as a garment buyer. Use hidden cameras. You can make powerful films this way (McDougall 2008a\&b). Filmmaking difficulties were part of the narrative. In one scene, for example, 'the journalist is creeping up on a refugee camp to film some appalling act of capitalism, whispering the words 'the Indian government doesn't allow filming here, but we're hoping to get some footage" (LeeMoore $2011 \mathrm{np}$ ).

Primark complained to the BBC's Editorial Complaints Unit (ECU) about McDougall's exposé. They claimed that a 45 second scene - in which three boys were seen testing the stitching on sequined tops in Bangalore - had been faked (Methven 2011: Figure 2). The needles used were too large for such delicate work. The tight camera focus was suspicious. No other garments were visible. For example (Hickman 2011b np). 22 months later, the ECU cleared the production team but said their filming 'was not subject to sufficient scrutiny ... and should not have been relied on in the programme' (in Robinson 2010 3). Primark then appealed to the broadcaster's governing body, the BBC Trust. After watching unedited film rushes, examining emails and gathering witness evidence from the field (Ayling 2011, Revoir 2011), Primark published a 'myth-busting' video and the Trust concluded that 'only [McDougall], his translator and the witness 'would ever know the truth of the circumstances under which the footage was shot" (Leroux $2011 \mathrm{np}$ ).

One statement in the Trust's report was seized upon by Primark: that 'there was not one piece of irrefutable and conclusive evidence which would enable it to say for certain (i.e. 
beyond reasonable doubt) whether the footage was or was not staged. ... [But] on the balance of probabilities, it was more likely than not that the Bangalore footage was not authentic' (in Greenslade $2011 \mathrm{np}$ ). So, Primark triumphantly stated, 'We feel vindicated and we are delighted that after three years of pursuing this issue, the BBC Trust had finally confirmed that the film was fake' (in Gloger 2011 17). 'Millions of people', it said, 'have been deceived by Panorama. Viewers who watched the programme, shoppers who were then fed the lie, ... teachers and pupils who viewed the programme in lessons, have all been badly let down' (Primark nd np).

\section{LEGO: When you buy a LEGO container ship to make with your interns}

In 2007, the container ship MSC Napoli was run aground off the South West of England. 103 containers fell into the sea and were washed ashore on beaches where hundreds of people traveled to 'salvage' their contents (Cook and Tolia-Kelly 2010). Over 90\% of the world's cargo travels by sea. Container ships are 'The forgotten space' of global capitalism (Sekula and Burch 2010). We'd researched this. In 2012 a toy catalogue arrived in the mail advertising a new container ship set, a collaboration between Denmark's most famous companies: LEGO (the world's largest toy company: Davidson 2014) and Maersk (the world's largest container shipping company: Maersk 2015). I found a YouTube review by BeanMeister22 (2011), a merchant seaman who'd assembled one. He compared it with the real thing. 'Chances are, no matter where in the world you live,' he said, 'your LEGO sets were transported on a ship very much like this one' (np). Wow. I just had to get and make one for my research. This is how LEGO became the toy we experimented with.

That summer, interns Eeva Kemppainen, Jack Parkin and Ellie Bird and Brown University summer school students Diana Shifrina and Sabrina Skau were working with me in Exeter on the followthethings.com project. I bought this LEGO ship with the project money that 
also funded their work and studies.ii I created a Storify page including all of the online news stories, videos and blogs I knew about container ships and shipwrecks (followthethings.com 2012). I set up a laptop in the office in a top floor 'Flat' of the University's Hatherley Building that became our LEGOlab. We watched and read these reports as we built our ship, piece by piece, carefully following the instructions. We tweeted our progress and making-conversations via @followthethings and hoped our 'live' build might gain interest online.iii We could use the completed ship to re-create images of the Napoli disaster, I thought. I borrowed my daughter's LEGO collection to provide the extra pieces we'd need. We 're-created' iconic images of the Napoli running aground, the string of debris washed up along the coastline, two men wheeling a $£ 25,000$ motorbike up the beach and people rolling large oak wine barrels away from the scene.iv Given the pieces available, we could not do this accurately. The only LEGO motorbike available in Exeter's Toys'R'Us, for example, was a purple Batbike. This was pushed up our beach by the Batman and Catwoman Minifigures that came with it. This was the wreck of another ship. The kind that brought your LEGO to you. Run aground on the Hatherley Flats on the mid-Devon coast, spilling its cargo along the shore. That, at least, was what we said in the captions of the images we uploaded to Flickr, posted on Facebook and tweeted via @followthethings. 


\section{Primark: When BBC journalists drown their sorrows}

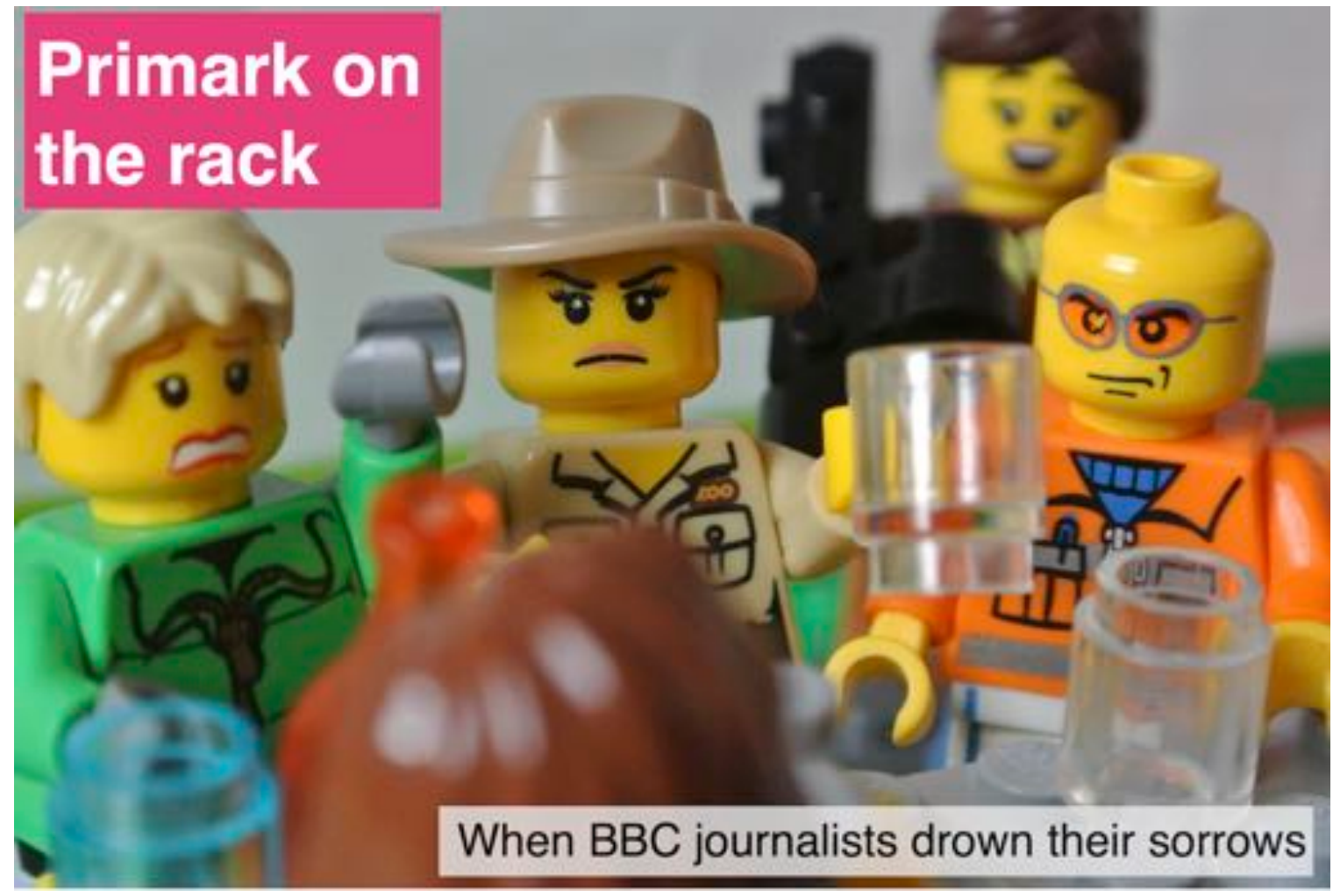

Figure 3.

In the wake of the BBC Trust's report and Primark's triumphalist press releases, BBC journalists were angry and worried. Primark were 'abusing the BBC complaints procedure', had 'cherry-picked' the Trust's Report, were telling 'outrageous lies' about its findings and were 'far from vindicated' (Tan $2011 \mathrm{np}$ ). Even with 45 seconds edited out, the film still showed that 'Primark suppliers were exploiting workers who were made to work long hours for minimal pay' (War on Want $2011 \mathrm{np}$ ). Journalists and commentators 'hit out at the [BBC's] complaints procedure, accusing it of caving in to powerful companies' (Robinson 2010 3). Dan McDougall, who had refused to speak to the Trust's investigators, "vigorously' rejected the ... findings of the inquiry', saying 'I have rarely seen a finding so unjust in outcome, flawed in process and deeply damaging to independent investigative journalism" (in Garner $2011 \mathrm{np}$ ). Worse was to come. The Trust instructed the BBC to broadcast an apology to Primark in a future Panorama programme (Robinson and Sweney 2011), to hand back the Royal Television Society award the film had won in 2009 (Leroux 
2011) and to say what measures it would take in future to prevent 'further breaches of its editorial guidelines' (Goldfingle $2011 \mathrm{np}$ ). Primark would wait on these 'measures' before it decided whether or not to sue for damages (ibid.).

After three years of concerted attack, Primark boasted, the BBC's investigative journalism had been put 'on the rack'. Its Trust was effectively accusing McDougall and his team of breaching editorial guidelines and of unethical journalistic behaviour (Greenslade 2011). McDougall the exposer had now been 'exposed' (johnjm $2011 \mathrm{np}$ ). Accusing anticapitalist critics of double standards is a well-honed tactic employed to undermine their critiques (Sandlin \& Milam 2009). Journalists and commentators speculated whether McDougall should seek a judicial review of the Trust's findings, sue Primark for libel (Greenslade 2011, emilynew 2011) and/or whether, 'if [he] sues for libel, he will ruin his own reputation' (antifrank $2011 \mathrm{np}$ ). Concerns were expressed that the Trust's report 'batter[ed] the credibility of what has been a well regarded programme' and 'could lead to public scepticism' of the series as a whole (Kaba 2011 15). In the wake of a successful complaint against another Panorama programme in 2009 , a BBC insider admitted that 'A lot of the high-profile undercover work has been dropped from documentaries ... It's too risky now we are nervous about broadcasting anything that has a serious chance of ending up in court' (in Hirsch 2009 7). Across the British TV industry programme makers said that compliance to editorial guidelines was having a negative effect on their 'creativity' (Strauss $2011 \mathrm{np})$. TV executives were self-censoring and the results were 'clear on screen: safe, dull programmes' (ibid.). Risky programme ideas were being pitched first to commercial rival Channel 4 and, 'If it says no, then a 'safer' version goes to the BBC' (ibid). 


\section{LEGO: When you to make things together}

Eeva, Jack, Ellie, Diana and Sabrina worked with me for six weeks. During our first week, Tony Perucci helped us develop our critical creative faculties through two days of performance activism training. Eeva and the others then spent the following two and a half weeks in their Hatherley Flats office finishing selected undergraduate-created pages to publish on followthethings.com before passing them to me for final editing and publishing (Cook et al 2014). After this, I promised, we would spend our final three weeks creating new work informed and inspired by the examples we had researched. This work would also be published on the website. We had no idea what this would involve. But Tony's training gave us an ethos and the shipbuilding and wreck re-creations gave us valuable experience of working creatively with materials. Diana explained: 'LEGO [bricks] were everywhere ... Somehow, organically, unexpectedly, we got the idea to start making our [pages] in ... LEGO... We weren't in front of a computer screen, didn't have to edit references, and let our imaginations be channelled through our favourite childhood activity ... [Our Office] was now filled with the noise of LEGO [bricks] being shuffled around, interspersed with people asking for a specific red piece or a Minifigure with a sad face' (Shifrina $2012 \mathrm{np})$.

Sabrina, for example, 're-created' the moment when two participants in the 2009 TV series 'Blood Sweat and Takeaways' scuffled in an Indonesian tuna-processing plant before one was sent home in disgrace (for Clarke at al 2013). And Eeva re-created a scene from the factory suicide level of the smartphone game Phone Story (for Kemppainen et al 2012). We did not only 're-create' photographs, film stills and screen-grabs, though. We also 'recreated' scenes described on their followthethings.com pages, conjured up by, or imagined 'between the lines' of, the conversations we'd arranged there. We 're-created' single scenes to capture key moments and series of scenes 're-creating' a narrative of the 
example and/or its making and reception. Each scene was photographed, adjusted, photographed, adjusted ... until its image clicked and was uploaded to Flickr. On each image's Flickr page, we added catchy captions, the original textual fragments they 'recreated', links to their followthethings.com pages and a credit to their maker(s). We embedded them on their followthethings.com pages and tweeted links to the filmmakers, artists, authors, NGOs and others who made and/or were featured in them. We hoped they would reply and/or share our work across their networks. One who did so was James Christie Miller (nd), director/producer of 'Blood, sweat and take-aways' TV series. 'I love the immortalisation in LEGO,' he wrote, 'it neatly sums up all the emotions in the series perfectly!' We were on to something and were excited to make more.

\section{Primark: When you learn about the 'Streisand effect'}

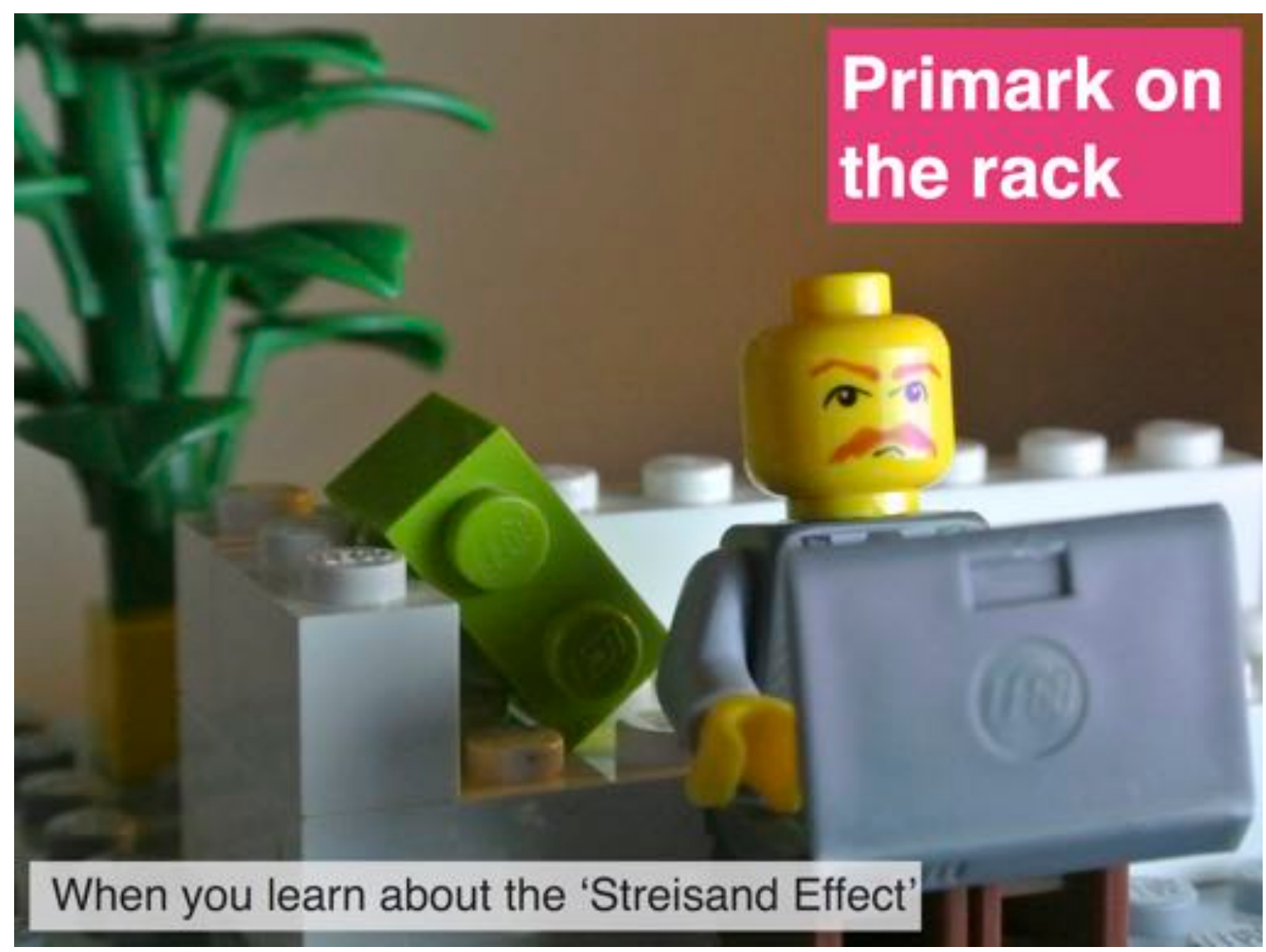

Figure 4.

'Primark vs. the BBC' was a very public battle. Over a thousand people emailed contributions to a BBC 'Have Your Say' debate (Anon 2008). Dozens of newspaper 
reports were published online, and numerous, sometimes fierce, discussions developed in their comments. Others blogged, shared reports and posted comments on social media (see Adley et al 2013). This was a slowly unfolding scandal. A flagship TV series was faking footage to expose a fast fashion chain. A fashion chain removed from its stores clothes featured in a documentary, cut ties with their manufacturers and tried to silence a critique of its unethical practices. It was more worried about its reputation than the welfare of those making its clothes, a reputation that a sophisticated PR strategy was supposed to repair before anyone noticed it had been tarnished. Commentators argued. After the BBC Trust report was published in 2011, Paul Lister - 'company secretary and director of legal services at Primark's parent company Associated British Foods' - said there had been no noticeable consumer boycott of Primark as a result of the film. But Google-searching 'Primark' and 'Sweatshop' continued to return thousands of hits, 'all as a result of this programme'. Panorama had made Primark the 'poster boy of child labour'. Lister concluded (in Sweney $2011 \mathrm{np}$ ). Why had its attempts to silence its critics backfired so badly?

The Streisand Effect. In February 2013, EDF sued for $£ 5$ million some climate change activists who had occupied the chimney of a power station in the UK (Monbiot 2013). If EDF won, the activists would lose everything. This, George Monbiot wrote, was an 'attempt to bully people into political submission through inordinate demands' (ibid. nd). If such legal action was successful, those who 'might otherwise have been trying to protect the environment or ... defend workers' rights are ... snarled up in the courts. Those who might have joined the campaign are frightened off. Those who might have become active in other campaigns avoid politics altogether for fear of the consequences' (ibid. np). But this, he said, was a risky response by EDF to its critics. In 2003, Barbra Streisand's lawyers had demanded $\$ 50$ million in damages for the violation of the entertainer's 
privacy. They insisted an aerial photograph of her house be removed from an online collection of photos taken for the California Coastal Record project (Anon 2003). Before the lawsuit, it had been downloaded four times. A month after, it had been downloaded 42,000 times. The 'Streisand Effect', Wikipedia explains, is 'the phenomenon whereby an attempt to hide, remove, or censor a piece of information has the unintended consequence of publicising the information more widely, usually facilitated by the internet' (Anon nd np). This is what happened to Primark. I imagined its Minifigure CEO reading Monbiot's column late one night at home. A penny dropping (Figure 4). The final scene in the series. I thought.

\section{LEGO: When you pay attention to the materials you're working with}

Most people have played with a LEGO as children and/or as adults with children. First patented in 1958 it is now sold in over 130 countries (Bartneck et al 2013). There are hundreds of brick shapes in dozens of colours (Aesthetics for Birds 2014), and seventy five bricks for each member of the human population (Bartneck et al 2013). All are made from the same 'colourfast and durable acrylonitrile butadiene (ABS) plastic' and have the same stud-and-tube interlocking system (Baichtal and Meno 2011 13) meaning that '15 to 20-year-old parts are still compatible with current sets' (ibid.). Snapping and overlapping them on a Cartesian grid baseplate, LEGO builds remain rigidly in place (Lee 2014). Theorists argue that the unique combination of 'the rigidity of discrete, digital and atomistic bricks with the continuity and flow of plastics' (ibid. 98) enables a visceral exploration of 'the constructedness of the material world through a central play experience simultaneously about building worlds and playing with and within those worlds' (ibid. 102). LEGO claims its system of play 'embod[ies] a democratic philosophy of things fitting together ... an ethic of thoughtfulness, caring and playing together ... [which] can help build a mindset that is creative, optimistic and willing to try new things' (Gauntlett 2014191 
and 202-3). Its Minifigures are the 'centrepiece of any LEGO set' (Bartneck et al 2013, 2). Now with cartoon-like faces expressing LEGO's 'full range' of emotions - disdain, confidence, fear, happiness and anger (ibid.) - they enable the role-playing of human relationships in the spaces and structures created. Their yellow skin tone - so the philosophy continues - represents 'the universal and raceless imagination of children' (ibid., Johnson 2014a).

Minifigures provide vivid means to play identity politics. Neither male nor female exhibits secondary sexual characteristics. So 'the default is asexual or male, depending on your point of view' (Baichtal and Meno 2011 59). Femininity is marked by lipstick, eyelashes, removable long, flowing or bunned hair, clothing designs suggesting breasts, fabric skirts, and other accessories to, or replacements for, legs. But, for every one female 19 male Minifigures have been made. All had the standard yellow skin tone until 2003 when LEGO introduced 'natural skintones' in franchised sets with 'already raced star/character' Minifigures like, for example, basketball star Kobe Bryant and film character Indiana Jones (Johnson 2014b 315). These sets spurred LEGO's rise to the world's largest toy company, but their racialisation has caused confusion among the AFOL (Adult Fans of LEGO) and LEGO theorist communities. Does the marketing of Minifigures with both a default yellow and multi-hued skintones represent LEGO's 'corporate reluctance, lack of interest, confusion, or sensitivity about representing bodies' (Johnson 2014b, 313)? Whatever the answer, it's clear that LEGO is political before you tip it out of the box. 


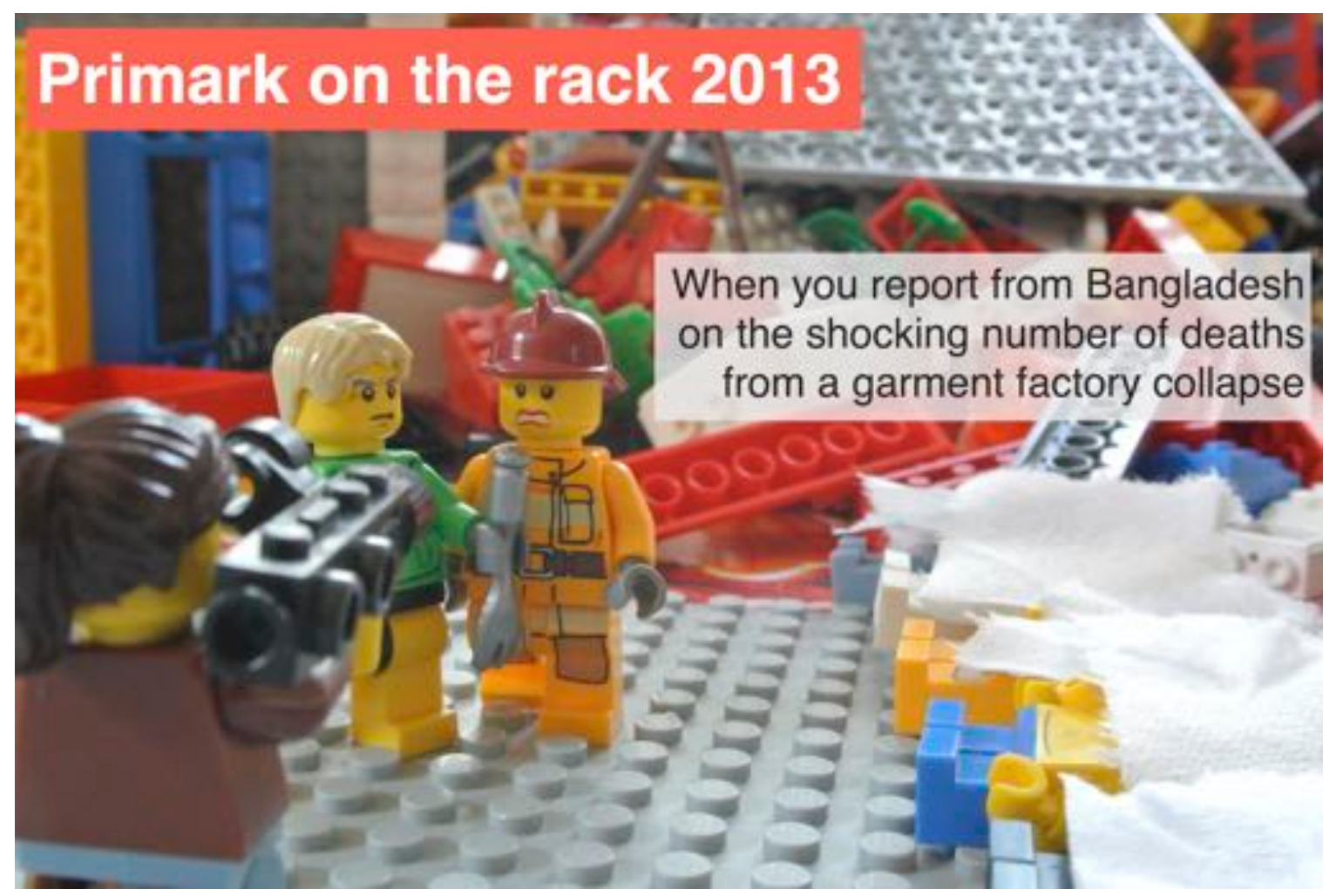

Figure 5.

On Tuesday 23 April 2013, two inch deep cracks were discovered in three pillars inside the Rana Plaza garment factory complex in Savar, near Dhaka, in Bangladesh. The building housed a bank and shops on its ground floor and six ready-made garment factories on seven floors above. 4,000 to 5,000 people worked there. A local engineer inspected the cracks, classified the building as 'vulnerable' and recommended it be immediately surveyed. TV and newspaper reports of the cracks appeared. Concern spread among the workforce. The next day, the bank and shops didn't open. But the majority of female garment workers entered the building and began to assemble High Street brands' clothing as usual. That month's pay would be withheld if they refused and they were reassured via the factories' loudspeakers that the cracks had been repaired. Most men stayed outside. At 8.37am a power cut led to generators on every floor being switched on. Those inside heard a loud sound like the cracking of toast biscuits, felt the building jerk beneath their 
feet and rushed shouting towards the gates in the East side as the middle of the floor collapsed. Many tried to escape via staircases or by jumping out of windows. But the North wall broke apart and the building tilted South and imploded into a 7,000 ton, two-story high pyramid-shaped pile of rubble. Over 3,500 people were killed, injured and trapped. The owner Sohel Rana was quickly rescued from his basement office and whisked away by car (Ahmed and Lakhani 2013, al-Mahmood 2013a, Alam 2013, Akhter 2014, Harvey 2014, Manik and Yardley 2013, Warner et al 2013).

Thousands of soldiers, police, fire fighters, social welfare agencies, relatives and members of the public gathered at the scene to rescue survivors and to identify the dead and injured. Numbers rose rapidly, day after day. Journalists documented heroic rescue efforts and people pulled from the rubble alive after days underground told stories of terrifying experiences. Firefighters wept live on television after failing to rescue a woman called Shahnaz 110 hours after the collapse when a fire broke out in the rubble and killed her (Anon 2013a, Anon 2013b). Photos of dead bodies appeared in news stories with their feet protruding from the sheets placed over them. Three weeks later, over 1,100 were dead and over 2,000 had been rescued alive (Odhikar 2013, Kabir \& Saha 2013). I retrieved the journalist Minifigures who had previously drowned their sorrows and put them in a new scene, interviewing a firefighter Minifigure beside a row of garment workers Minifigures, dead on the ground, their feet protruding from sheets made from ripped tissue paper (Figure 5). This was the first scene in an altogether darker and surprising follow-up series made and posted online as this tragedy and its repercussions unfolded.

\section{LEGO: When you join the world of LEGO artists, AFOLs and MOC vigs}

If you've seen the LEGO Movie, you'll remember the film's central dramatic tension between the ordered building of boxed LEGO sets according to the instructions and the 
freestyle 'MOC' ('my own creation') LEGOing that draws upon a person's eclectic mix of bricks, Minifigures and accessories (Garlen 2013). Some commentators worry that this freestyle play has been pushed aside by the proliferation of franchised LEGO sets (Giddings 2014, 250). But MOC LEGOing comes alive after each new set has been built, dismantled and its pieces added to a larger box of the dismantled remains of other previously-built sets. Here, the values of the LEGO Group are subverted by 'dark play'. While children create and play with 'world[s] of great flux, anarchy and disaster often without resolution ... [with] crazy titles, morals, and characters' (Sutton Smith in ibid. 261, Woodyer 2012a), artists have played with the Minifigure's innocence in startlingly horrific ways, 'fiddling with its image and placing it in strange, sometimes disturbing situations, [and] building ... upon its iconic potential in ways profoundly emblematic of our time' (Bramadi 2013, 26). In the AFOL community, these scenes are known as 'vigs' (or vignettes). Since the mid 1990s, AFOLs have uploaded, shared and discussed over a million LEGO photographs on web platforms like Flickr (Garlen 2013).

By disembodying and recombining Minifigures' heads, hairpieces, torsos, arms, hands, legs and accessories, you can carefully pose a handful together in simple scenes which 'serve a single snippet of drama' (Baichtal and Meno 2011 165). These can be quickly made with impressive results .You rummage through your bricks, Minifigures and accessories to find inspiration. You dismantle, collect, click, assemble, pose and place pieces together in a rough scene, take it apart, rework it, ask for help finding pieces, explain what you're trying to achieve, until you get the feeling that you know what you're doing, how it will turn out, what it will show, how it will photograph and how audiences might be affected by it (Garlen 2013). Reflecting on our builds, Sabrina said there was 'something almost wrong but deliciously fun about taking innocent little children's toys and using them to depict the more violent and unsavoury aspects of human action and 
experience'. We described the scenes we re-created and the images we published on Flickr as hilariously uncomfortable, powerful, awful in a good way, tasteless, carefully shocking, dark and spooky. We hoped they might be cute or provocative enough to spark further discussion. Even if others weren't affected by seeing them, by making and photographing them we had had to discuss and think through more deeply the complex issues and emotions we were trying to convey (in Woodyer 2012b np). This was material poetry, politics, conversation, worlding (Lee 2014, Tolia Kelly 2013, Carr and Gibson 2016, Lorimer 2013).

Primark: When you realise your legal and PR teams will never be able to argue that this footage is fake

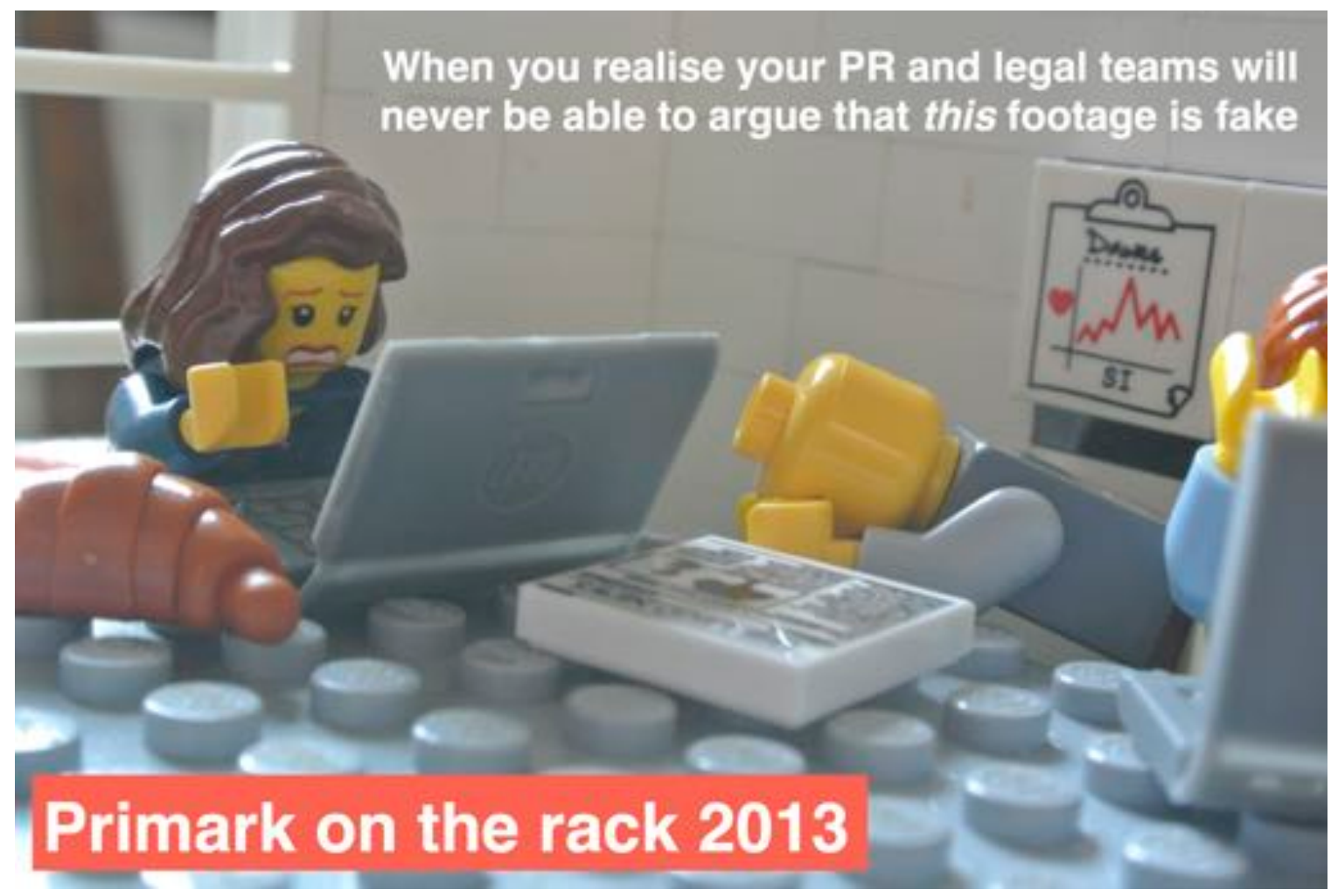

Figure 6.

The 24 hour coverage of the Rana Plaza collapse was a different kind of exposé of the manufacture of High Street clothing and the lives of the people working in the factories where it was made. Journalists from all over the world working for countless media organisations documented what was happening and questioned the companies whose 
clothes were - without any doubt - being made by those dead and injured workers. They found Benetton, Mango, Primark and other brands' clothes in the rubble, photographed them and included these photos in their reports. They reported that New Wave Bottoms, on Rana Plaza's second floor, listed Primark as a buyer (Anon 2013c, Gayle 2013). The UK's Daily Mail newspaper described Rana Plaza as the 'Primark factory disaster' (Gayle 2013). News headlines included 'Rescuers use massive strips of cloth as escape chutes after Primark factory in Bangladesh collapses (Reilly 2013); '119 dead at Bangladesh plant that supplies Primark' (Hammadi et al. 2013); 'Why I never shop at Primark: ... almost 300 die in the Bangladesh factory tragedy' (Dacre 2013); and 'Protesters outside Primark's flagship London store call for fashion chains to compensate families of dead and injured' (al-Mahmood 2013b). Primark was by far the most prominent brand mentioned in news stories as the shocking scale of the tragedy quickly emerged.v The responsibilities and reputation of this 'poster boy' of garment factory carnage - along with a growing list of other companies - were discussed worldwide (see, for example, Anon 2013d, Anon 2013e, Anon 2013f, Kuenssberg 2013, Neilan 2013, O'Connor 2014, Stout et al 2013, Ward 2013, Winterstein 2015 and Yardley 2013).

The Rana Plaza collapse was a different kind of exposé, an event so spectacular that journalists were drawn to it en masse to convey the mounting scale and shock of its human suffering. After decades of anti-sweatshop campaigning, journalists reported NGOs arguing that Rana Plaza had to be an ethical turning point in the global fashion industry (Kennedy 2014, Siddiqui 2015). This exposé couldn't be framed as the unethical work of a rogue journalist employed by a media company with an alleged anti-business bias. No PR agency could 'move this story on'. Primark would have to respond differently. Figure 1 would have to be reassembled. The same white office walls, table, laptops, chart and Minifigures with a new LEGO newspaper tile centre stage. One Minifigure would have a 
new head with a different, terrified expression. All would have different postures, gently arranged and photographed to create and capture a wildly different atmosphere (Figure 6). These corporate Minifigures couldn't attack their critics. They were in crisis mode.

\section{LEGO: When you learn that what you're making is Political LEGO}

Sharing our re-creations on social media, we got into conversations. @angelalast said we were making 'political LEGO'. Look at the work of artist Zbigniew Libera, she advised (Last 2012). In 1996, he exhibited seven boxed LEGO-branded Nazi Concentration Camp sets made from standard LEGO pieces donated by the company (Baictal and Meno 2011, Bramadi 2013).vi 'The larger boxes showed the entire concentration camp, with buildings, gallows ... and inmates behind barbed wire or marching in line in and out of the camp.... [And] a crematoria belching smoke from three chimneys, with sonnderkammando or other inmates carrying a corpse from the gassing room. The smaller boxes depict a guard bludgeoning an inmate, medical experiments, another hanging, and a commandant, reminiscent of something more from the Soviet Gulag than the Nazi concentration camp system, as he is bedecked with medals and wears a red hat.... The last box is one full of possessions, the type of debris painted by other artists and inspired by the vast array of loots collected by the S.S. in the Kanada warehouses in Birkenau' (Feinstein 2000 3). Audiences at a 1997 conference on contemporary art and the Holocaust 'pelted Libera with a barrage of insults from 'You're an anti-Semite' to 'This is not art' (ibid. 4). In 2002 his sets were exhibited at the 'Mirroring Evil' exhibition at New York's Jewish Museum (Kleeblatt 2002) and in 2012 were acquired by the Museum of Modern Art in Warsaw (Anon 2012). They had a rich quality. People 'couldn't stop discussing' them (Van Alphen 2002 165). 
Look too at the work of Legofesto, Last (2012) advised. Between 2007 and 2009 she recreated in LEGO and posted on Flickr iconic photos from the 'War on Terror' in albums called 'Police Brutality at the G20', 'Guantanamo Bay', 'Sri Lanka Bombing', 'Abu Ghraib' and 'Darfur'.vii Watching her son 'throwing his Minifigures into a toy prison', she said, 'made me think about how we're dehumanising people, we're treating them as if they had no more moral value than a toy figurine' (in Carling 2009, np). She took published photos, drawings and/or victim testimonies, stripped them down to their shocking essentials, recreated them as simple LEGO sculptures, and snapped and/or burned their Minifigures, bricks and accessories to 'make it clear that our concern ... should be for the fate of the people' (Legofesto 2013 np). Both 'sanitising and horrifying' (Mackey 2009, np) she hoped those who saw these scenes would 'linger longer' (Pickert 2009, np), share them online and 'keep the memory of what happened ... alive' (Mackey 2009, np) 'even after the news cycle had moved on' (Anon 2009 np). Journalists wrote about them and the scenes they re-created. Freed Guantanamo Bay prisoner Moazzem Begg told her that he'd used them 'to explain to his children what he had been through' (Carling 2009, np). Our work was in this tradition. 


\section{Primark: When you see that people died making your clothes}

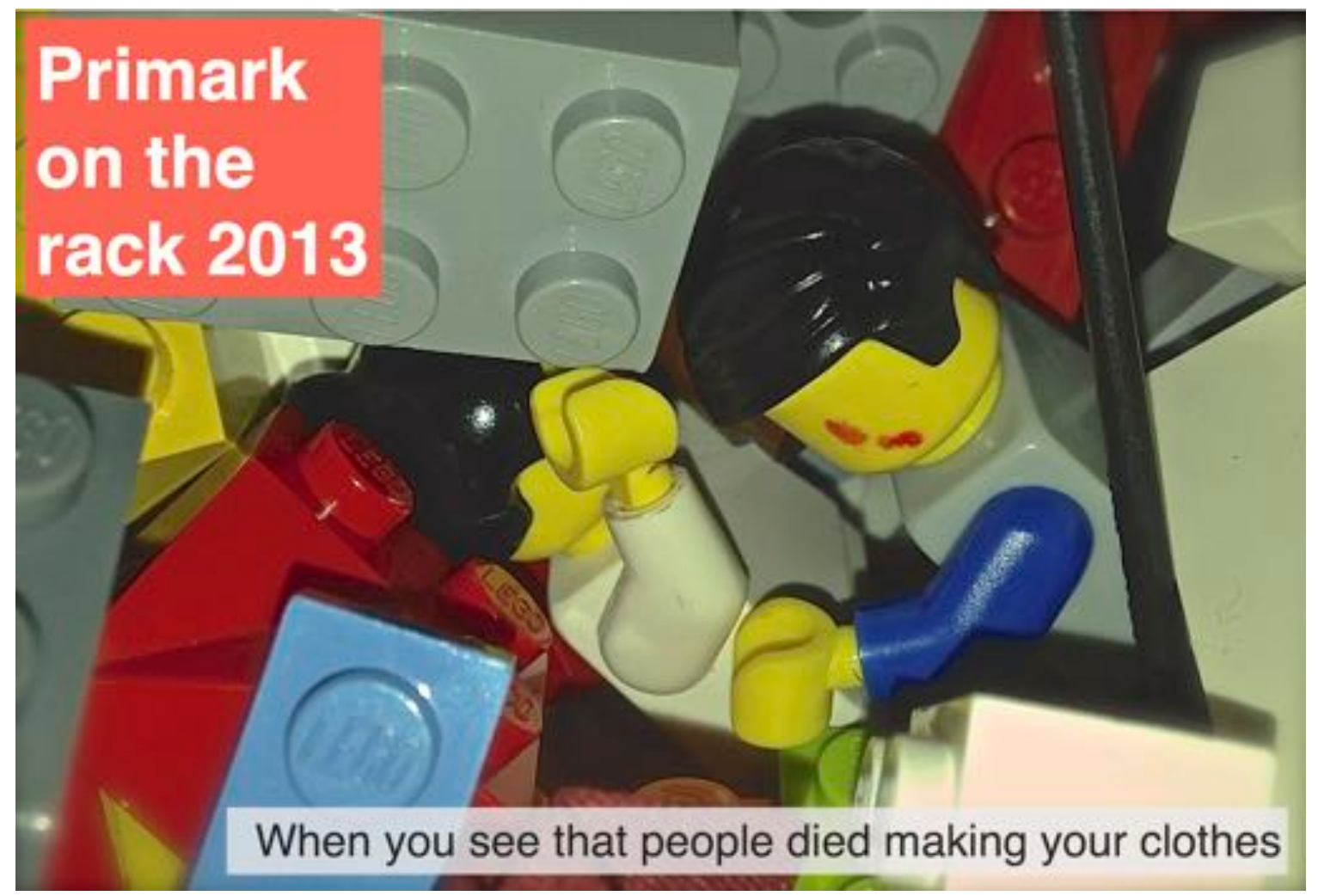

Figure 7.

Crushed. Torn apart. Ground like corn between millstones. Trapped. People. In masonry 'collapsed at so many angles and in such precarious ways that any wrong move could cause a fresh tragedy' (Anon $2013 \mathrm{~g} \mathrm{np}$ ). Rescuers, ignoring the protruding arms, legs and torsos of those already dead. Looking for crevices. Scrambled. Listening for survivors. Moaning, praying and pleading for help below. Drilling, digging and crawling their way towards them. Digging, pulling and easing them out. Carrying them to safety. Leaving the army's heavy lifting gear unused to begin with. Rescuers wearing 'cheap Bangali chapal sandals, white t-shirts and jeans or trousers' (Nelson and Berghman $2013 \mathrm{np}$ ). Using ladders, drills, welding tools, bottles of water, whistles, oxygen cylinders, torches. Moving rubble via human chains. Finding pockets of 40,70, 100 people alive underground. Routes to them often blocked by dead bodies. And survivors trapped by masonry. Pleading. 'A pillar has fallen over me. Please someone save me. Cut my hands to free me' (in Anon 2013h np). Limbs amputated in place. Sometimes with anaesthetic. Often with a hand saw 
or knife. Screaming. Especially when saw or knife met bone (Smith 2013). Friends and coworkers trapped nearby. Alive, dying, dead, then rotting. Men in surgical masks spraying disinfectant and air freshener. Volunteers holding signs asking for 'more air freshener, oxygen, water, scissors, and bandage[s]' (Jianghua and Karim 2013 np). Crowds applauding each live rescue. Relatives unable to identify crushed and decomposed bodies.

Taslima Akhter was there, taking photographs. 'Around 2am', she said, 'I found a couple embracing each other in the rubble. The lower parts of their bodies were buried under the concrete. The blood from the eyes of the man ran like a tear. When I saw the couple, I couldn't believe it. I felt like I knew them - they felt very close to me. I looked at who they were in their last moments as they stood together and tried to save each other - to save their beloved lives. Every time I look back to this photo, I feel uncomfortable - it haunts me. It's as if they are saying to me, we are not a number - not cheap labour and cheap lives. We are human beings like you. Our life is precious like yours, and our dreams are precious too' (in Anon and Akhter 2013 np). Heart crushing, overwhelming, creepy, sad, staged, beautiful, this photo was shared countless times online and became the iconic image of the disaster (Scotford 2013). Millions signed online petitions in which it featured demanding that fashion brands admit complicity, pay compensation, and ensure this could never happen again. 2013 intern Nancy Scotford re-created it in LEGO. no Minifigure face had the right expression. So she twisted one to the blank side and drew a bloody tear with a ballpoint pen (Figure 7).

\section{LEGO: When your feelings feed it and it comes alive}

If you flick between this paper's figures, you'll see. The same head. Yellow. Slightly raised eyebrows. A distant stare. A moustache. A downturned line for a mouth. Stern. Pointing to 
a bumpy sales graph. In an office. Overseeing his PR team's attack on their critics. Figure 1. Later, face lit up by his laptop screen. At home. Having just realised his mistake. Figure 4. Later, back in the office. Banging his head on the table. Overwhelmed by circumstances. Figure 6. Finally, alone in the office. Phoning. Disappointed. Impatient. Figure 8. Next. Another head. Differently raised eyebrows. A hint of eyelashes. Short blonde hair. A lipsticked mouth. Open, crumpled with dread. Staring into the distance. In a bar. A journalist. Drowning her sorrows. Figure 3. That head appearing later. In another scene. On the body of a firefighter. Helmeted. Crying at the scene of a deadly garment factory collapse. Being interviewed by that journalist. With another head, face, expression. Moved. Figure 5. The same head. Again. Back in the office. Now the face of the PR / legal executive. Seen before. With dark flowing hair. Then with a confident, determined face. Figure 1. Now staring at her laptop screen. With horror. As her boss collapses in despair. Figure 6. Any, all heads. Turned to the blank side. With a single bloody tear. Drawn in the sticky ink of a biro. Could be dead in the rubble. Figure 7. Minifigures posed in relation to others, accessories and bricks. Exactly in line or at right angles to one another. Later, on one leg. Rotated a little. Resting at angles on surfaces. On rigidly clicked together structures. Hairline fractures between bricks clearly showing. Bricks loose in a pile. Made from the same ABS plastic. A common LEGO humanity (Zielke 2015). Equally uncrushable. Unlike human bodies. Scenes constructed with intimacy and care. Dramas. Unfolding across multiple interrelated sites. In photos captioned 'When you...'. Like a Barbara Kruger postcard (Rose 1995). Or a cat meme. To quickly 'convey jokes or support ideas and arguments' online (Mel $2012 \mathrm{np}$ ).

Viewers look. Imagine. Enter these scenes. Mentally take them apart. With their own hands. Children's hands. Re-make them. Or something like them. Knowing other worlds are possible. Because these scenes are clearly constructed (Sawaya 2014). Human. 
LEGO. Bodies. Touching. Encountering one another. Making. A form of knowledge that is first of all affective instead of cognitive' (Van Alphen 2002 178). Each scene 'a moment in time of an oppressive situation' (Saxon 2012 62) which can 'inspire viewers to imagine what happens before and after' (Baichtal and Meno 2011 165). Provocatively bringing the there and then into the here, now and future. LEGOing persectives. In political LEGO 'soliciting partial and temporary identification with ... perpetrators contributes to an awareness of the ease with which one slides into a measure of complicity' (Van Alphen 2002 178). But instructions don't have to be followed. Other worlds can be - and are made (Feinstein 2000, Kleeblatt 2002). That's why Libera made those concentration camp sets.

Primark: When you phone your competitors asking why you're the only company offering compensation

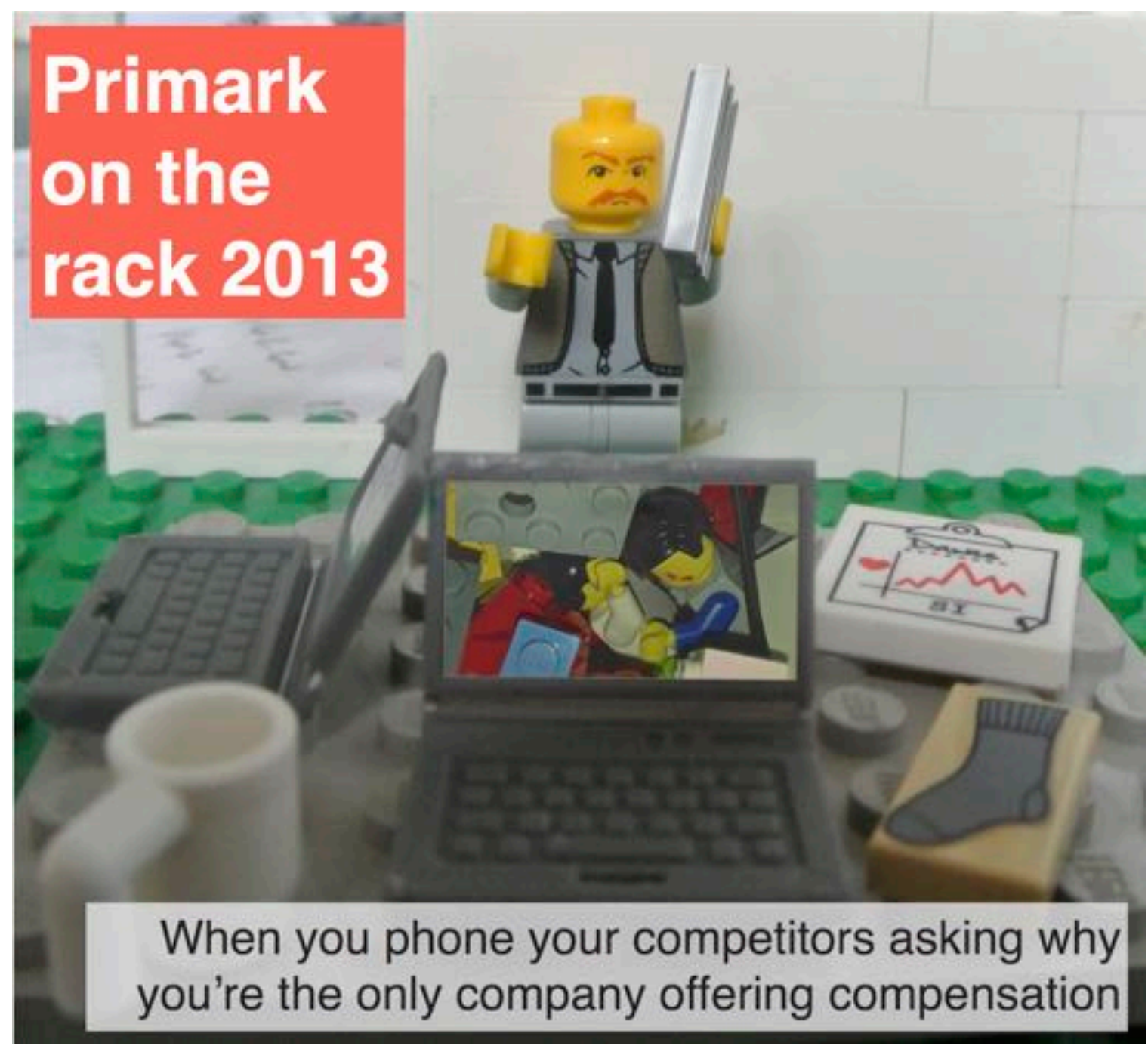




\section{Figure 8.}

Brands whose labels and paperwork were found in the Rana Plaza rubble said that 'they were not involved with factories at the time of the collapse or had not recently ordered garments from them' (Alam and Garjon 2013 np). Except one: Primark. Who immediately said it was 'shocked and deeply saddened by the appalling incident' (in Gayle $2013 \mathrm{np}$ ). Expressed 'its condolences to all of those involved' (in Anon 2013i np). Sent its 'ethical trade team ... to collect information, assess which communities the workers come from and provide where possible' (Anon 2013j np). Made available its 'local banking infrastructure in Bangladesh to deliver any funds that are made available on an emergency basis' (Clean Clothes Campaign $2013 \mathrm{np}$ ). Addressed 'the immediate needs of victims, including the provision of emergency food aid to families'. Accepted 'all its responsibilities in the this disaster'. All within 4 days of the collapse, the BBC reported (2013 np). It would provide, for the New Wave Bottoms victims, 'long-term aid for children who have lost parents, financial aid for those injured and payments to families of the deceased' (ibid.). It urged other brands 'to come forward and offer assistance' (in Saini $2013 \mathrm{np}$ ) and paid the wages of 3,630 survivors who had made clothes for them - and for their rivals - for six months after the collapse (Smith and Dowling $2013 \mathrm{np}$ ).

In September 2013, 29 brands sourcing from Rana Plaza were invited to the International Labour Organisation in Geneva to discuss a proposed US $\$ 75 \mathrm{~m}$ compensation fund for the victims (Talaga 2013). Twenty failed to turn up. Companies like Walmart, Benetton and Mango were showing 'total contempt' for those killed and injured said the Clean Clothes Campaign (2013 np). Primark attended and added £6m to the fund (US\$10m). Gilbert Houngbo, Deputy Director General of the ILO, hoped this exemplary response would 'bring the debate out so that people will ask other brands 'What are you doing?" (Butler $2014 \mathrm{np}$ ). Primark again 'call[ed] on other brands sourcing from Rana Plaza to now 
contribute a fair share' (in Talaga 2013 np: Figure 8). In March 2014, it made its 'last long term payment' to the New Wave Bottoms victims but said it would 'remain involved to support dependents until adulthood' (Anon 2016 np). By May 2015, 19 of the 29 brands had paid into the fund (Clean Clothes Campaign 2015 np). 'Primark continues to remember the people who died in the Rana Plaza building', say news stories documenting its continuing trading success (e.g. Burke and Sexton $2016 \mathrm{np}$ ). 'Lessons had been learned from ... the tragedy [and] it is possible to make clothes in Bangladesh without putting workers at risk', the company says (in Anon 2013k np). Primark spent $£ 9$ million to turn its Rana Plaza story around (Croft 2016). This process was masterminded by a familiar figure: Associated British Food's Paul Lister. Journalists reported (Anon 2016).

\section{Conclusion: when you assess the æffect of your work}

In this paper, we have tried to draw together forms of academic research, making and composition that can have powerful affects + effects $=$ æffects (Duncombe 2016). We're convinced that this art-activist approach can create deeper, more visceral understandings of the kinds of geographical controversies that might conventionally be examined and conveyed with the total earnestness that their gravity seems to demand. But advocates of art-activism approaches say that when this work works it 'lures us, pushes us, seals us up inside, and then rejects us feeling sick, stirred, titillated, sullied, betrayed, contaminated, and embarrassed. And shaken, perhaps, with deeply unfathomable questions' (Spitz 2002 43). Its handiwork can allow us to approach 'subjects that are almost impossibly hard to handle, where questions of truth and artifice are fraught with special urgency, both psychologically and politically' (Hatfield in Scherr 2013, 20). And 'by being evocative, compassionate, angry, painful or funny, [it] ... can produce an empathic response from the reader / listener that can help sensitise them to a particular issue, experience, place or group of people' (Madge 2014 181). 
The main question asked of art-activist work, however, is 'Does it work?' (Duncombe 2016). We have to address this. We could tell you exactly how many times each of our images has been viewed on Flickr. But these are only numbers. We are sure that our work has made no measurable difference to Primark as a corporation or to garment workers in Bangladesh. We know it has moved people with whom we have shared it, and have included above the feedback that encouraged our experimentations. The main æffects, however, have been on us and, we hope, on you as you have made your way through this paper. So, to conclude, we'd like to ask you six questions: has this paper a) revealed a reality by providing factual information about a little-known social issue; b) altered perception by providing different vantage points on familiar topics; c) fostered dialogue around such 'uncomfortable or overlooked topics'; d) invited your participation less as a consumer and more as a producer of such work; e) encouraged experimentations with an expectation of 'new and unintended results'; and/or f) created an 'imminent cultural shift ... in the way [you] think or talk about an issue, or whether [you] think about it al all' (Duncombe 2016 121-4)? You know the answers. So why not re-create, with others, scenes from your research in LEGO, or My Little Pony, Action Man (see Yusoff 2007), Minecraft, Hello Kitty, any toy system recognized and available around the world and where you live? Choose a toy system that works with whatever you're researching, and whoever you're working with. Make scenes together to post in public places. See how this shapes conversations and affects understandings. Creative practice is not always easy. But you / we can do this.

\section{Acknowledgements}

This paper's 'et al' includes followthethings.com collaborators Keith Brown, Eeva Kempainnen, Sabrina Skau, Jack Parkin, Ellie Bird and Diana Shifrina; sounding boards 
Tara Woodyer, Matt Hockenberry, Angela Last, Nick Gill, Paula Crutchlow and the Cultural and Historical Geographies Research Group at the University of Exeter; anyone who responded to our LEGO talks in Exeter, Bristol, Aberystwyth, Leicester and Paris; Simon Naylor and the three anonymous referees who helped make this paper shipshape; and the University of Exeter International Office who funded our work.

\section{References}

Adley K, Keeble R, Russell P, Stenholm N, Strang W and Valo T 2013 Primark: on the rack. (http://www.followthethings.com/primark.shtml) Accessed 27 July 2015

Aesthetics for Birds 2014 Interview with Philosopher and LEGO sculptor Roy T Cook. (http://www.aestheticsforbirds.com/2014/03/interview-with-philosopher-lego_5.html) Accessed 7 July 2015

Ahmed S and Lakhani L 2013 Bangladesh building collapse. CNN.com 13 May Akhter S 2014 Endless misery of nimble fingers Asian journal of women's studies 20(1) $137-147$

Alam J 2013 Bangladesh factory collapse death toll hits 1,038 Associated Press 10 May Alam J and Garjon A-E 2013 Workers pinned in Bangladesh rubble cry for rescue Associated Press Financial Wire 25 April

al-Mahmood SZ 2013a Bangladesh building collapse The Guardian 25 April al-Mahmood SZ 2013b Protesters outside Primark's flagship London store call for fashion chains to compensate families of dead and injured The Observer 28 April Anon nd Streisand Effect (https://en.wikipedia.org/wiki/Streisand_effect) Accessed 16 February 2016

Anon 2003 Barbra Sues Over Aerial Photos (http://www.thesmokinggun.com/documents/celebrity/barbra-sues-over-aerial-photos) Accessed 16 February 2016 
Anon 2008 Primark: On The Rack - Panorama Preview - Monday, 23th June 2008, 9pm, BBC One (http://www.ethical-junction.org/blogs/2008/06/20/primark-on-the-rackpanorama-preview-monday-23th-june-2008-9pm-bbc-one/) Accessed 23 February 2013 Anon 2009 Lego torture scenes protest media censorship (http://www.wired.com/culture/art/multimedia/2009/05/gallery_lego_torture) Accessed 28 June 2010

Anon 2012 Warsaw art museum buys Zbigniew Libera's 'Lego' concentration camp (http://latimesblogs.latimes.com/culturemonster/2012/01/lego-concentration-camp-warsawmuseum.html) Accessed 20 June 201616

Anon 2013a Fire breaks out at site of Bangladesh factory collapse, killing last known survivor (http://worldnews.nbcnews.com/_news/2013/04/28/17956849-fire-breaks-out-atsite-of-bangladesh-factory-collapse-killing-last-known-survivor) Accessed 16 June 2016 Anon 2013b One lost life among the hundreds epitomizes Bangladesh tragedy Japan Economic Newswire 29 April

Anon 2013c Dozens dead after factory supplying Primark collapses in Bangladesh The Telegraph 24 April

Anon 2013d Disaster at Rana Plaza (http://www.economist.com/news/leaders/21577067gruesome-accident-should-make-all-bosses-think-harder-about-what-behavingresponsibly) Accessed 7 June 2016

Anon 2013 e Dhaka puts pressure on fashion stores (http://www.bangkokpost.com/print/347894/) Accessed 7 June 2016 Anon 2013f Primark pimpt binnenstad De Telegraaf 19 September 17 Anon 2013g Death toll rises to 142 in Bangladesh building collapse BBC Monitoring South Asia 25 April

Anon 2013h Dhaka building collapse toll soars to 191 Indo-Asian News Service 25 April 
Anon 2013i Bangladesh garment trade blamed as disaster toll hits 175. Agence France Presse 25 April

Anon 2013j Cries for help from the rubble of Dhaka factory as death toll nears 200 Evening Standard 25 April

Anon 2013k Clothing retailer Primark to pay more compensation to Bangladesh building collapse victims Big News Network 24 October

Anon 2016 The Hot 100 2016: in-house The Lawyer 25 January

Anon and Akhter T 2013 A final embrace (http://lightbox.time.com/2013/05/08/a-finalembrace-the-most-haunting-photograph-from-bangladesh/\#1) Accessed 20 June 2013 antifrank 2011 Comment on Greenslade R 2011 Why the BBC Trust is wrong to have found against Panorama (http://www.guardian.co.uk/media/greenslade/2011/jun/16/bbctrust-investigative-journalism?INTCMP=SRCH) Accessed 28 June 2012

Armistead C and Jones J 2015 Artwork showing Sylvanian Families terrorised by Isis banned from free speech exhibition (https://www.theguardian.com/artanddesign/2015/sep/26/sylvanian-families-isis-freedomof-expression-exhibition) Accessed 19 September 2017

Ayling J 2011 UK: Primark exposé footage rules 'fake' (http://www.juststyle.com/news/primark-exposé-footage-ruled-fake_id111362.aspx) Accessed 1 March 2013

Baichtal J and Meno J 2011 The cult of LEGO San Francisco, No Starch Bartneck C, Obaid M and Zawieska K 2013 Agents with faces. What can we learn from LEGO Minifigures. Proceedings of the 1st International Conference on Human-Agent Interaction, Sapporo

BBC 2013 Dhaka collapse: Primark to pay victims compensation (http://www.bbc.co.uk/news/business-22346220) Accessed 27 June 2016 
BeanMeister22 2011 LEGO Maersk Container Ship Review: \#10155 New for 2011 (https://www.youtube.com/watch?v=zqGEBLeiC_4) Accessed 4 August 2015

Bramadi L 2013 Legoramart Los Angeles: Muttpop

Brassett J 2009 British irony, global justice: a pragmatic reading of Chris Brown, Banksy \& Ricky Gervais Review of International Studies 35 219-245

Burke R and Sexton C 2016 Primania The Sunday Business Post 29 May

Butler S 2014 Primark pays £6m more to Rana Plaza victims

(https://www.theguardian.com/world/2014/mar/16/primark-payout-victims-rana-plazabangladesh) Accessed 27 June 2016

Carling A 2009 Throwing plastic bricks at torturers because words bounce off (http://www.andycarling.com/2009/05/throwing-plastic-bricks-at-torturers-because-wordsbounce-off/) Accessed 29 May 2015

Carr C and Gibson C 2016 Geographies of making: rethinking materials and skills for volatile futures Progress in human geography 40(3) 297-315

Christie Miller J nd Peer review (http://followthethings.com/peerreview.shtml) Accessed 3 June 2016

\section{Clarke H, Thomson B, Bartley V, Ibbetson-Price K, Christie-Miller E and Schofield H} 2013 Blood, sweat \& takeaways (http://followthethings.com/takeaways.shtml) Accessed 17 June 2016

Clean Clothes Campaign 2013 Bangladesh workers must continue to wait for full compensation (http://www.cleanclothes.org/news/press-releases/2013/09/12/bangladeshworkers-must-continue-to-wait-for-full-compensation) Accessed 27 June 2016

Clean Clothes Campaign 2015 Who has paid and who is dragging their heels (http://www.cleanclothes.org/safety/ranaplaza/who-needs-to-pay-up) Accessed 28 June 2016 
Cook et al I 2014 Fabrication critique et web 2.0: les géographies matérielles de followthethings.com Géographie et cultures 91-92 23-48

Cook et al I 2017 From 'follow the thing: papaya' to followthethings.com Journal of Consumer Ethics 1(1) 22-29

Cook I and Tolia-Kelly D 2010 Material geographies. in Hicks D and Beaudry M eds Oxford handbook of material culture studies Oxford, Oxford University Press 99-122 Cook I and Woodyer T 2012 Lives of things. in Sheppard E, Barnes T and Peck J eds Wiley-Blackwell companion to economic geography Oxford, Wiley-Blackwell 226-241

Croft C 2016 The march of the Primaniacs The Sunday Times 26 June

Dacre K 2013 Why I never shop at Primark The Evening Standard 26 April

Davidson $\mathbf{J} 2014$ Lego is now the largest toy company in the world (http://time.com/money/3268065/lego-largest-toy-company-mattel/) Accessed 7 June 2016 Duncombe S 2016 Does it work? The æffect of activist art Social research 83(1) 115-134 emilynew 2011 Comment on Greenslade R 2011 Why the BBC Trust is wrong to have found against Panorama (http://www.guardian.co.uk/media/greenslade/2011/jun/16/bbctrust-investigative-journalism?INTCMP=SRCH) Accessed 28 June 2012

Feinstein S 2000 Zbigniew Libera's Lego Concentration Camp Other voices: the (e)journal of cultural criticism 2(1) 1-9

followthethings.com 2012 followthethings.com's LEGO ship. (https://storify.com/followthethings/followthethings-com-likes-lego-container-ships) Accessed 28 June 2015

Garlen J 2013 Block party: a look at Adult Fans of LEGO in Barton K and Lampley J eds Fan CULTure Jefferson NC, Mcfarland 119-130

Garner S 2011 Panorama Documentary Primark: On The Rack 'probably had faked footage' (http://www.metro.co.uk/news/866634-panorama-documentary-primark-on-therack-probably-had-faked-footage) Accessed 28 June 2012 
Gauntlett D 2014 The LEGO System as a tool for thinking, creativity and changing the world in Wolf M ed Lego Studies London, Routledge 189-205

Gayle D 2013 Daughter's agony as she discovers her mother is among 230 dead in Primark factory disaster while rescuers fight to save survivors screaming in the rubble Daily Mail 25 April

Giddings S 2014 Bright bricks, dark play: on the impossibility of studying LEGO in Wolf M ed Lego Studies London, Routledge 241-267

Gloger D 2011 BBC shamed for fake child slavery footage (http://www.express.co.uk/news/uk/253205/BBC-shamed-for-fake-child-slavery-footage) Accessed 1 March 2013

Goldfingle G 2011 Jewellers alarmed as Channel 4 targets them over gold mines (http://www.retail-week.com/sectors/fashion/jewellery/jewellers-alarm-as-channel-4targets-them-over-gold-mines/5026551.article) Accessed 23 February 2013

Greenslade R 2011 Why the BBC Trust is wrong to have found against Panorama (http://www.guardian.co.uk/media/greenslade/2011/jun/16/bbc-trust-investigativejournalism?INTCMP=SRCH) Accessed 28 June 2012

Gross M and Do E 2009 Educating the new makers: cross-disciplinary creativity Leonardo $42(3) 201-215$

Hammadi S, Burke J and Smithers R 2013119 dead at Bangladesh plant that supplies Primark The Guardian 25 April

Harvey B 2014 Emerging initiatives in the aftermath of Rana Plaza in Bangladesh Professional safety May 66-68

Hickman M 2011 BBC returns prize for 'faked' Primark show i 29 June, 22 Hirsch A 2009 Destination libel (http://www.guardian.co.uk/media/2009/jun/15/libeltourists-taranissi-bbc) Accessed 1 March 2013 
Hockenberry M 2013 Follow the things (http://supplystudies.com/2013/07/29/follow-thethings/) Accessed 29 June 2015

Jianghua Z \& Karim N-U 2013 Wails rend air as bodies pulled out of collapsed building in Bangladesh Philippines News Agency 25 April

johnjm 2011 Comment on Greenslade R 2011 Why the BBC Trust is wrong to have found against Panorama (http://www.guardian.co.uk/media/greenslade/2011/jun/16/bbctrust-investigative-journalism?INTCMP=SRCH) Accessed 28 June 2012

Johnson D 2014a Chicks with bricks in Wolf M ed Lego Studies London, Routledge 81104

Johnson D 2014b Figuring identity: media licensing and the racialisation of LEGO bodies International journal of cultural studies 17(4) 307-325

Jones B, Temperley J and Anderson L 2009 Corporate reputation in the era of Web 2.0: the case of Primark Journal of Marketing Management 25(9-10) 927-939

Kaba N 2011 Dismiss Panorama at your peril

(http://www.prweek.com/uk/news/1078625/Dismiss-Panorama-peril/) Accessed 23

February 2013

Kabir AAF and Saha A 2013 Primary fact-finding report, ASK Investigating Unit (http://www.askbd.org/ask/wp-content/uploads/2013/11/Rana-Plaza-ASK-PreliminaryInvestigation-Report.pdf) Accessed 16 June 2016

Kemppainen E, Edwards C, Bain T, Wrede W, Biddulph S and Hall S 2012 Phone Story (http://followthethings.com/phonestory.shtml) Accessed 15 December 2016

Kennedy B 2014 Is the Bangladesh factory collapse a turning point?

(http://www.cbsnews.com/news/is-the-bangladesh-factory-collapse-a-turning-point/) Accessed 20 June 2016

Kleeblatt N 2002 Zbigniew Libera: LEGO Concentration Camp Set. in Kleeblatt N ed Mirroring evil: Nazi imagery / recent art New Brunswick, Rutgers University Press 129-131 
Kneip V 2009 Political struggle within the market sphere in Baringhorst S, Kneip V and Niesyto J eds Political campaigning on the web Bielefeld, Transcript 173-198

Kuenssberg L 2013 Primark: Time rivals also pay Bangladesh factory victims

(http://www.itv.com/news/2013-10-24/primark-time-rivals-also-pay-bangladesh-factoryvictims/) Accessed 7 June 2016

Last A 2012 More political Lego links for you! (http://twitter.com/angelalast/statuses/231109431973261312) Accessed 20 June 2016 Lee J 2014 The plastic art of LEGO in Weiss D, Propen A and Emerson Reid C eds Design, mediation and the posthuman Lanham: Lexington Books, 95-112

LeeMoore 2011 Comment on Greenslade R 2011 Why the BBC Trust is wrong to have found against Panorama (http://www.guardian.co.uk/media/greenslade/2011/jun/16/bbctrust-investigative-journalism?INTCMP=SRCH) Accessed 28 June 2012

Legofesto 2013 Exhibition (http://legofesto.blogspot.co.uk/2013/09/exhibition.html) Accessed 20 June 2016

Lehmann A-S 2012 Showing making: on visual documentation and creative practice The journal of modern craft 5(1) 9-24

Leroux M 2011 BBC returns award for Panorama Primark programme with 'faked' footage The Times 25 June np.

Lorimer H 2013 Materialities in Johnson N, Schein R and Winders J eds The WileyBlackwell companion to cultural geography Oxford. Wiley-Blackwell 32-34

Mackey R 2009 Visualizing torture, with Lego (http://thelede.blogs.nytimes.com/2009/05/05/visualizing-torture-with-lego/?hp\&_r=0) Accessed 29 May 2015

Madge C 2014 On the creative re(turn) to geography: poetry, politics and passion Area 46(2) 178-185 
Maersk 2015 Maersk Line (http://www.maersk.com/en/hardware/fleet/maersk-line) Accessed 4 August 2015

Magee K 2008 Primark uses web to counter BBC

(http://www.brandrepublic.com/news/822908/) Accessed 1 March 2013

Manik JA and Yardley J 2013 Building Collapse in Bangladesh Kills Scores of Garment Workers New York Times 25 April

Marston S and De Leeuw S 2013 Creativity and geography: towards a politicised intervention Geographical journal 103(2) iii-xxvi

McDougall D 2008a The hidden face of Primark fashion

(http://www.guardian.co.uk/world/2008/jun/22/india.humanrights) Accessed 1 March 2013 McDougall D 2008b Primark Sweatshop exposed

(http://news.tootoo.com/Apparel_Fashion/Garment_Accessories/20080624/118928.html)

Accessed 1 March 2013

Mel 2012 Talking memes (http://platformlondon.org/2012/09/07/talking-memes/) Accessed 24 June 2016

Methven N 2011 BBC forced to apologise to Primark for 'faked' Panorama scenes (http://www.mirror.co.uk/tv/tv-news/bbc-forced-to-aplogise-to-primark-for-faked-135457) Accessed 1 March 2013

Mezzadri A 2011 'Bonded capital' and the organisation of home-working in India (http://www.iss.nl/News/Events/Bonded-Capital-and-the-Organization-of-Home-Workingin-India-Development-Research-Seminars) Accessed 4 November 2011

Monbiot G 2013 Will EDF become the Barbra Streisand of climate protest? (https://www.theguardian.com/commentisfree/2013/feb/25/edf-west-burton-streisandeffect) Accessed 30 June 2016 
Neilan C 2013 Fashion's moral crisis in Bangladesh

(http://www.drapersonline.com/news/fashions-moral-crisis-in-

bangladesh/5048777.fullarticle) Accessed 7 June 2016

Nelson D and Bergman D 2013 Bangladesh dispatch: the 'miracle' of Rana Plaza gives way to grief as body count rises The Telegraph 25 April

O'Connor C 2014 These retailers involved in Bangladesh factory disaster have yet to compensate victims (http://www.forbes.com/sites/clareoconnor/2014/04/26/these-retailersinvolved-in-bangladesh-factory-disaster-have-yet-to-compensate-victims/\#4197e51b57c5) Accessed 7 June 2016

O'Flynn K 2012 Toys cannot hold protest because they are not citizens of Russia, officials rule (https://www.theguardian.com/world/2012/feb/15/toys-protest-not-citizens-russia )

Accessd 19 September 2017

Odhikar 2013 Broken dreams: a report on the Rana Plaza collapse. Odhikar: Bangladesh Pickert K 2009 Lego violence

(http://content.time.com/time/nation/article/0,8599,1896362,00.html) Accessed 29 May 2015

Primark nd Primark statement, Primark and BBC Panorama: the true story (http://www.primarkresponse.com/panorama/primark-statement/) Accessed 27 June 2012 Ratto M Wylie S and Jalbert K 2014 Introduction to the Special Forum on Critical Making as Research Program The information society 30, 85-95

Reilly J 2013 Rescuers use massive strips of cloth as escape chutes after Primark factory in Bangladesh collapses killing at least 96 people Daily Mail 24 April

Revoir P 2011 Panorama 'faked scene of Primark child labour' (http://www.thisismoney.co.uk/money/news/article-1727294/Panorama-faked-scene-ofPrimark-child-labour.html) Accessed 1 March 2013 
Robinson J 2010 BBC clears Panorama of faking scene in Primark documentary (http://www.guardian.co.uk/media/2010/apr/04/bbc-panorama-primark-complaints) Accessed 1 March 2013

Robinson J and Sweney M 2011 BBC to apologise on air to Primark for Panorama Documentary (http://www.guardian.co.uk/media/2011/jun/16/bbc-to-apologise-on-airprimark?INTCMP=SRCH) Accessed 28 June 2012

Rose G 1995 Making space for the female subject of feminism in Pile $\mathbf{S}$ and Thrift $\mathbf{N}$ eds Mapping the subject London, Routledge 332-354

Sacks S 2004 Foreword in Harlan V ed What is art? Conversations with Joseph Beuys Forest Row, Clairview ix-xii

Saini M 2013 Demands for action as death toll mounts Women's Wear Daily 30 April Sandison N 2008 Panorama's Primark report pulls in 4.2m for BBC One (http://www.brandrepublic.com/news/822351/Panoramas-Primark-report-pulls-42m-BBCOne/?HAYILC=RELATED) Accessed 1 March 2013

Sandlin J and Milam J 2008 'Mixing pop culture and politics': culture jamming and anticonsumption activism as critical public pedagogy Curriculum inquiry 38(3) 323-50

Sawaya N 2014 LEGO: the imperfect art tool in Wolf M ed Lego Studies London, Routledge 206-215

Saxon L 2012 Image theatre in Boyd A ed Beautiful trouble: a toolbox for revolution New York, O/R 62-3

Sayev N 2015 The meltdown of Europe - as told by toys (https://www.theguardian.com/artanddesign/2015/oct/20/the-meltdown-of-europe-as-toldby-toys-playmobil) Accessed 19 September 2017

Scherr R 2013 Shaking hands with other people's pain: Joe Sacco's 'Palestine' Mosaic 46(1) 19-36 
Scotford N 2013 The Eternal Embrace (www.followthethings.com/eternalembrace.shtml) Accessed 22 June 2016

Sekula A and Burch N 2010 The forgotten space Amsterdam: Doc.Eye Film

Shifrina D 2012 LEGOs and LEGO Lab

(http://followthethings.tumblr.com/post/28078301991/legos-lego-lab) Accessed 4 August 2015

Siddiqi D 2015 Starving for justice: Bangladeshi garment workers in a 'post-Rana Plaza' world International labour and working class history 87,165-173

Smith N 2013 Stuck for 2 days, saved by saw The Sunday Times 28 April

Smith N and Dowling K 2013 Clothes chains fall short in disaster relief The Times 13 October

Spitz E 2002 Avant-garde Kitsch revisited in Kleeblatt N ed Mirroring evil: Nazi imagery / recent art New Brunswick, Rutgers University Press 39-52

Stout KL, Sparks J, Black P, Foster M, Davies A, Nichols R, Rivers D, Coren A, Ramos M \& Lah K 2013 Bangladeshi Garment Worker Protesters Demand Death Penalty For Building Owner CNN International news stream 30 April

Strauss W 2011 Does red tape have a stranglehold on TV? (http://www.broadcastnow.co.uk/popular-feeds/news-analysis/does-red-tape-have-astranglehold-on-tv/5029062.article) Accessed 1 March 2013

Sweney M 2011 Primark legal chief claims BBC made firm 'poster boy of child labour' (http://www.guardian.co.uk/media/2011/jun/16/bbc-primark-child-labour?INTCMP=SRCH) Accessed 28 June 2012

Talaga T 2013 Loblaw says it will help Bangladesh victims Toronto Star 25 October Tan K 2011 Comment on Cartmell 2011 Primark accuses Panorama of 'deceiving millions' following BBC Trust findings (http://www.prweek.com/uk/news/1075649/Primark-accusesPanorama-deceiving-millions-following-BBC-Trust-findings/) Accessed 28 June 2012 
Tolia-Kelly D 2013 The geographies of cultural geography III Progress in human geography $37(1)$ 153-160

Van Alphen E 2002 Toys and affect: identifying with the perpetrator in contemporary Holocaust art Australian and New Zealand journal of art 3(1) 158-190

War on Want 2011 War on Want disappointed at BBC Primark ruling (http://www.waronwant.org/component/content/article/17286) Accessed 1 March 2013

Ward J 2013 Primark labels in rubble of Bangladesh factory

(http://www.dailystar.co.uk/news/latest-news/311578/Primark-labels-in-rubble-of-

Bangladesh-factory) Accessed 7 June 2016

Warner M, Sparks J, Brown J, Woodruff J and Sreenivasan H 2013 PBS NewsHour 25 April

Winterstein I 2015 Two years on, garment workers still facing tough time The News Today 26 April np

Woodyer T 2012a Ludic geographies: not merely child's play Geography compass 6(6) 313-326

Woodyer T 2012b Lego: just imagine...

(https://materialsensibilities.wordpress.com/2012/09/05/lego-just-imagine-i/) Accessed 29 June 2015

Yardley J 2013 Tears and rage as hope fades in Bangladesh New York Times 29 April Yusoff K 2007 Antarctic exposure: archives of the feeling body Cultural geographies 14 $211-233$

Zielke J 2015 Political LEGO: an interview with Legofesto (http://followtheblog.org/2015/05/29/political-lego-an-interview-with-legofesto/) Accessed 7 July 2015 


\footnotetext{
i All of the images included in this paper were originally uploaded to this Flickr album https://www.flickr.com/photos/followthethings/albums/72157632897292738b but have been re-made for publication here.

ii For more information on the background and status of followthethings.com's interns and summer school students, see http://www.followthethings.com/faq.shtml

iii See https://twitter.com/search?q=\%23legoship\%20\%40followthethings\&src=typd

iv See the album at

https://www.flickr.com/photos/followthethings/sets/72157633178334474

${ }^{v}$ The top five brands/companies that feature in Rana Plaza news stories between 24 April 2013 and 16 June 2016 were Primark (557 stories), Matalan (468), Mango (355), Benetton (254) and Walmart (127). In the first five days of reporting, these brands appeared in Rana Plaza headlines: Primark (47 times), Matalan (once), Mango, Benetton and Walmart (0 times) (Nexis database 'all languages' search, 16 June 2016).

${ }^{v i}$ For more on Libera's sets, see http://raster.art.pl/gallery/artists/libera/libera_lego.htm

vii For more on Legofesto's sets, see https://www.flickr.com/photos/legofesto/albums
} 